\title{
Modifying chitosan with n-butyl acrylate - antibacterial ability
}

\author{
La Thi Thai Ha, Chau Ngoc Mai
}

\begin{abstract}
Polymer deriving from nature as Chitosan, which is one of the most abundant natural polymers in the world has effectively antibacterial potentiality. However, chitosan is relatively difficult for applications due to its disadvantageous properties.

In this article, modifying chitosan (CS) is the grafting copolymerization using monomer n-butyl acrylate (BA) and tert-butyl hydroperoxide (TBHP) as an initiator. This process purposes to attain product having lower glass transition temperature $\left(T_{g}\right)$ than original chitosan causing a wide range of applications but still keeping the capability of being an excellently antibacterial agent. The effects of parameters on synthesizing copolymer were studied by determining the grafting percentage $(G \%)$ and grafting efficiency $(\mathrm{E} \%)$. The results revealed that the highest $G=242 \%$ and $E=61 \%$ were obtained at the conditions as following: $\mathrm{BA} / \mathrm{CS}=4 \mathrm{w} / \mathrm{w}$, TBHP/CS $=5 \mathrm{v} / \mathrm{w}$ with $[\mathrm{TBHP}]=20 \mathrm{mM},[\mathrm{CS}]=$ $0.75 \% \mathrm{w} / \mathrm{v}$ in acetic acid $0.6 \%$ and reaction temperature $90^{\circ} \mathrm{C}$ in 6 hours.

Keywords-Antibacteria, chitosan; grafting copolymerization; n-butyl acrylate; tert-butyl hydroperoxide.
\end{abstract}

\section{INTRODUCTION}

$\mathrm{N}$ atural textiles such as those made from cellulose and protein fibers are considered to be vulnerable to microbe attack because of their hydrophilic porous structure and moisture characteristics. Therefore, the use of antibacterial agents to prevent or retard the growth of bacteria becomes a standard finishing for textile goods. On the other hand, there are many antibacterial agents to meet the increasing demand of human as well as considerable concerns about possible effects of antibacterial finishing on environmental and biological systems, toxic chemicals, lack of efficiency and durability.

Received: April 11 ${ }^{\text {th }}$, 2018; Accepted: Sept 19 $9^{\text {th }}$ 2018, Published: Dec 31 $1^{\text {st }}, 2018$.

La Thi Thai Ha, Ho Chi Minh City University of Technology, VNU-HCM (e-mail: lathaihapolyme@hcmut.edu.vn)

Chau Ngoc Mai, Ho Chi Minh City University of Technology, VNU-HCM (e-mail: cnmai.hcmut@gmail.com).
Thus, there is an increasing research effort to develop natural antibacterial coatings that fulfill three basic requirements: safe, durable and environmentally friendly

Chitosan is a $\beta-(1,4)$-linked polysaccharide of D-glucosamine, which is a deacetylated form of chitin, the second most abundant natural polymer in the world. They are obtainable from the shells of crabs, shrimps, and other crustaceans. This polymer is non-toxic, biodegradable and biocompatible natural, has long been used as a biopolymer and natural material in diverse applications. Chitosan is one of the safest and most effective antibacterial agents widely used for cotton and other textile antibacterials [1]. However, as mentioned for other biopolymers, chitosan has relatively poor mechanical properties, mainly involving low flexibility and brittleness, and reduced performance against water [2].

Chemical modification of chitosan, especially grafting with different polymers is an important topic in the production of bio-based materials with enhanced properties. In this way, chitosan presents two types of reactive sites which can potentially be modified by grafting copolymerization: C-2 free amino groups on deacetylated units and the C-3 and C-6 hydroxyl groups in either acetylated or deacetylated units [2].

Recently, there have been many kinds of researches related to this modification which applies to different applications: Copolymer PEG and chitosan as efficiently antimicrobial coatings for leather [3]; Synthesis, characterization and antimicrobial activity of biodegradable conducting polypyrrole-graft-chitosan copolymer [4], ... but grafting of vinyl monomers onto CS is one of the most effective approaches to improve the performances of CS without sacrificing its biodegradable nature [6]: Copolymer Chitosan and Methyl Methacrylate is demonstrated improvement of swelling, temperature glass transition $\mathrm{T}_{\mathrm{g}}$, decomposition temperature compared to Chitosan [5]; Chitosan-poly(glycidyl methacrylate) copolymer for immobilization to improve the thermal, $\mathrm{pH}$ and storage stability of the enzyme [7]; n-Butyl Acrylate in different proportions was 
grafted onto two different deacetylation degree (DD\%) chitosan to enhance the properties of these bio-based materials [2],... but there is no report focus on textiles applications of a copolymer.

In this research, n-butyl acrylate was chosen because its homopolymer performs low glass transition temperature $\mathrm{T}_{\mathrm{g}}$ and hydrophobic characteristics. These two important properties could be tailored to chitosan to get the desired results in the final product as improving its water resistance and mechanical properties [2] whereas antibacterial activity is maintained.

\section{MATERIALS AND METHODS}

\subsection{Materials}

CS (degree of deacetylation of $70 \%, \bar{M}_{\mathrm{w}}=9155$ $\mathrm{g} / \mathrm{mol}[10])$ from Vietnam is filtered after being completely soluble in acetic acid $0.6 \%$ (AA) (China); n-butyl acrylate (BA) (China) is purified by distillation; tert-butyl hydroperoxide solution 70\% (TBHP) (Aldrich).

\subsection{Grafting copolymerization}

CS solution was placed in a three-necked flask. Nitrogen was purged throughout the reaction time to remove air through stirring solution at room temperature. A freshly prepared TBHP solution $(20 \mathrm{mM})$ was added quickly at $80^{\circ} \mathrm{C}$ into the flask, which was continued heating up to $90^{\circ} \mathrm{C}$ and kept in 15 minutes. After that, BA was added dropwise into the reactor system to carry out the reaction for $6 \mathrm{~h}$ with stirring under nitrogen atmosphere. The obtained latex was dried at $80^{\circ} \mathrm{C}, 1$ atm to generate a film and remove remaining monomers. Finally, this film was released with $\mathrm{NaOH}$ solution, filtered, washed with distilled water until neutralized and dried after that.

Name of samples: $S_{a} X_{b} Y_{c}$ with 2 factors that affect the grafting copolymerization:

- $\mathrm{S}_{\mathrm{a}}$ : CS concentration, $\mathrm{a}=[0.75 ; 1 ; 1.5]$ (\% wt);

- $\mathrm{X}_{\mathrm{b}}$ : weight ratio of $\mathrm{BA} / \mathrm{CS}, \mathrm{b}=4$;

- $\mathrm{Y}_{\mathrm{c}}$ : volumn per weight ratio of TBHP/CS, $(\mathrm{ml} / \mathrm{g})$, $\mathrm{c}=[2 ; 7]$.

\subsection{Characterization of copolymer CS-g-PBA}

FT-IR spectra of the samples were conducted as $\mathrm{KBr}$ pressed discs on Tensor 27 Bruker IR spectrometer.

Particle sizes of latex after the reaction were determined directly by Laser Scattering Particle Size Distribution Analyzer LA-950.
Thermal analyses of the samples were performed with the DSC thermal analysis instrument. The specimens were heated at a heating rate of $10^{\circ} \mathrm{C} \cdot \mathrm{min}^{-1}$ under the $\mathrm{N}_{2}$ atmosphere from $-60^{\circ} \mathrm{C}$ to $200^{\circ} \mathrm{C}$.

The surface morphology of the product was examined by FE-SEM S-4800, Hitachi (Japan).

The antibacterial activity of CS-g-PBA was tested by S. Aureus and cotton in a zone of inhibition experiment with ASTM E2149-01. Cotton and Petri dishes are treated and sterilized by UV light before the test. $\mathrm{KH}_{2} \mathrm{PO}_{4}$ is used as buffer stock solution at $0.25 \mathrm{M}$ and working buffer solution at $0.3 \mathrm{mM}$ with this concentration is $1.0-1.5 \times 10^{-4} \mathrm{CFU} / \mathrm{ml}$.

Calculate the percent reduction of the organisms resulting from contact with the specimen using the following formula:

$$
\text { Reduction, \% }(\mathrm{CFU} / \mathrm{ml})=\frac{B-A}{A} \times 100
$$

Death Rate Constant (mean $\log _{10}$ density) = $B$ - A where:

$\mathrm{A}=\mathrm{CFU}$ per milliliter (or mean $\log _{10}$ density of bacteria) for the flask containing the treated substrate after the specified contact time, and $\mathrm{B}=$ " 0 " contact time CFU per milliliter (or mean $\log _{10}$ density of bacteria) for the flask used to determine "A" before the addition of the treated substrate.

Soxhlet extraction is utilized to assess product via grafting percentage $(\mathrm{G} \%)$ and reaction efficiency (E\%) [2]:

$\mathrm{G} \%=\frac{\text { weight of the grafted PBA }}{\text { weight of CS }} \times 100$
$\mathrm{E} \%=\frac{\text { weight of the grafted PBA }}{\text { weight of the total polymerized BA }} \times 100$

\section{RESULTS AND DISCUSSION}

\subsection{Preparation of $C S-g-B A$ copolymer}

Plausible grafting and particle formation mechanisms are proposed in Fig. 1. The hydroperoxide $(\mathrm{ROOH})$ initially interacts with amino groups on the polymer backbone, forming redox pairs. One electron is then transferred from nitrogen to $\mathrm{ROOH}$, resulting in the formation of a nitrogen cation radical and an alkoxy radical $(\mathrm{RO} \bullet)$. The subsequent loss of a proton from the nitrogen generates an amino radical, which is capable of initiating the graft polymerization of BA. The $\mathrm{RO} \cdot$ produced can either initiate homopolymerization of $\mathrm{BA}$ in the polymeric 
micelles or abstract a hydrogen atom from the polymer backbone, thus generating a backbone radical that can initiate BA graft copolymerization.

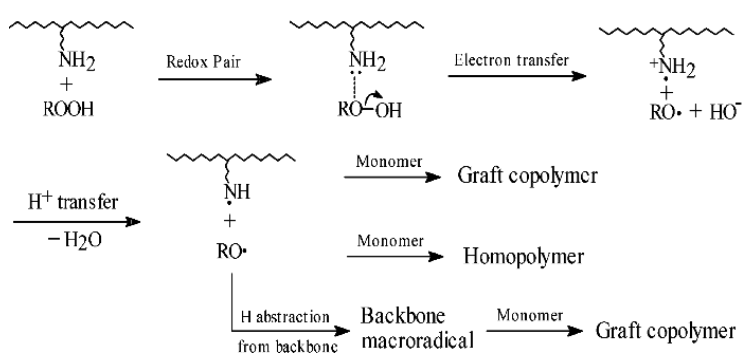

Fig. 1. Proposed mechanism for grafting BA into polymers containing amino groups [10]

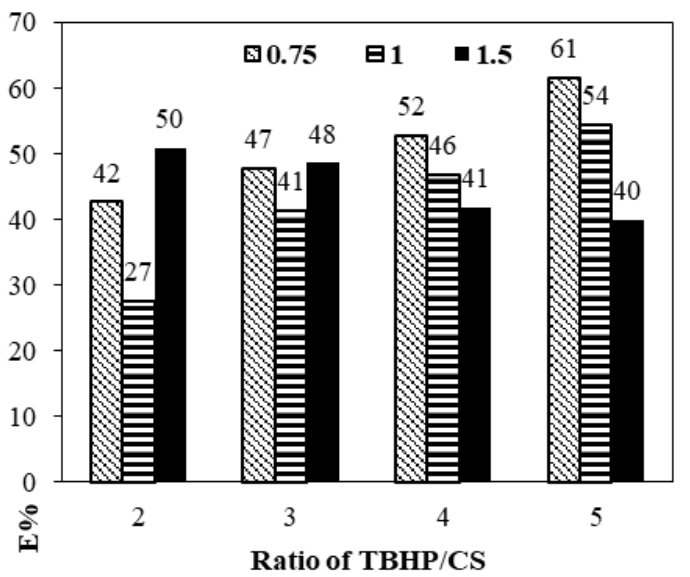

\subsection{Effect of chitosan concentration in acetic acid solution on $G \%$ and $E \%$}

It was apparent in Fig. 2 that $\mathrm{S}_{0.75}$ and $\mathrm{S}_{1}$ displayed upward trends of $\mathrm{G}$ and $\mathrm{E} \%$ but $\mathrm{S}_{0.75}$ were far higher than $S_{1}$ whereas $S_{1.5}$ had a downward trend by the variation of the CS concentration and TBHP content. It can be explained that at high CS concentration, these molecules were shielded and interacted with one another while at the low CS concentration, polymer chains can stretch freely and make it easier to create backbone macroradicals that initiate the grafting copolymerization. Thus, the highest $\mathrm{E}=61 \%$ and $\mathrm{G}=242 \%$ can only be obtained at $0.75 \%$ CS concentration in AA with $\mathrm{TBHP} / \mathrm{CS}=5 \mathrm{ml} / \mathrm{g}$.

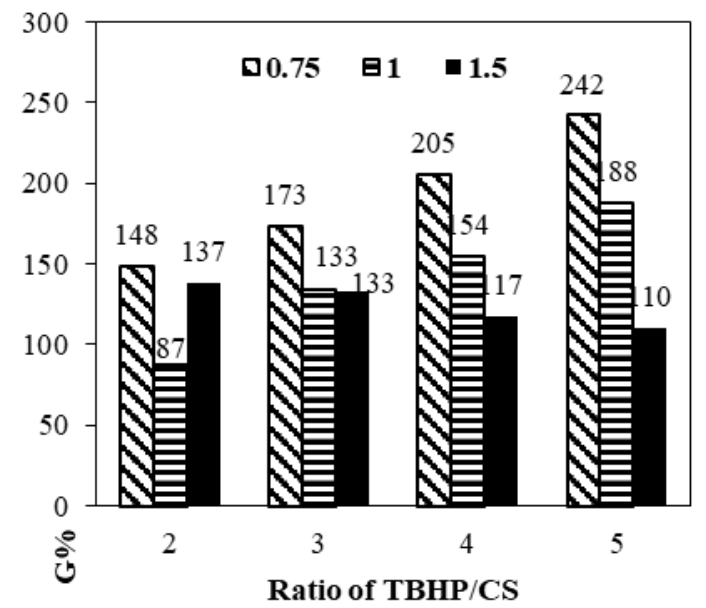

Fig. 2. Effect of CS concentration in AA solution on $E \%$ and $G \%$ of $S_{0.75} X_{4} Y_{c}, S_{1} X_{4} Y_{c}$ and $S_{1.5} X_{4} Y_{c}$ with $c=[2 ; 5]$.

\subsection{Effect of TBHP content on $G \%$ and $E \%$}

As the result above that $\mathrm{E} \%$ and $\mathrm{G} \%$,are growing with the increase of the ratio of TBHP/CS and have a high point at $5 \mathrm{ml}$ TBHP corresponding to $1 \mathrm{~g}$ CS in $0.75 \% \mathrm{CS}$ solution. Because of the upward trend of $\mathrm{S}_{0.75}$, whether or not it continues jumping when going up initiator content and keeping other conditions.

Fig. 3 shows that G\% and $\mathrm{E} \%$ reach the highest point at $5 \mathrm{ml}$ TBHP and both of them go down significantly then. This means the more initiator is added, the more tert-butoxy and hydroxyl free radicals are produced that subsequently initiate the homopolymerization of BA as well as grafting copolymerization. Even if free radicals are too much, radicals can be destroyed leading to a decrease in the number of radicals in solution and it does generally affect $\mathrm{G} \%$ and $\mathrm{E} \%$. Thus, $5 \mathrm{ml} \mathrm{TBHP} / 1 \mathrm{~g} \mathrm{CS}$ is the best content to obtain the highest $\mathrm{G}=242 \%$ and $\mathrm{E}=61 \%$. 


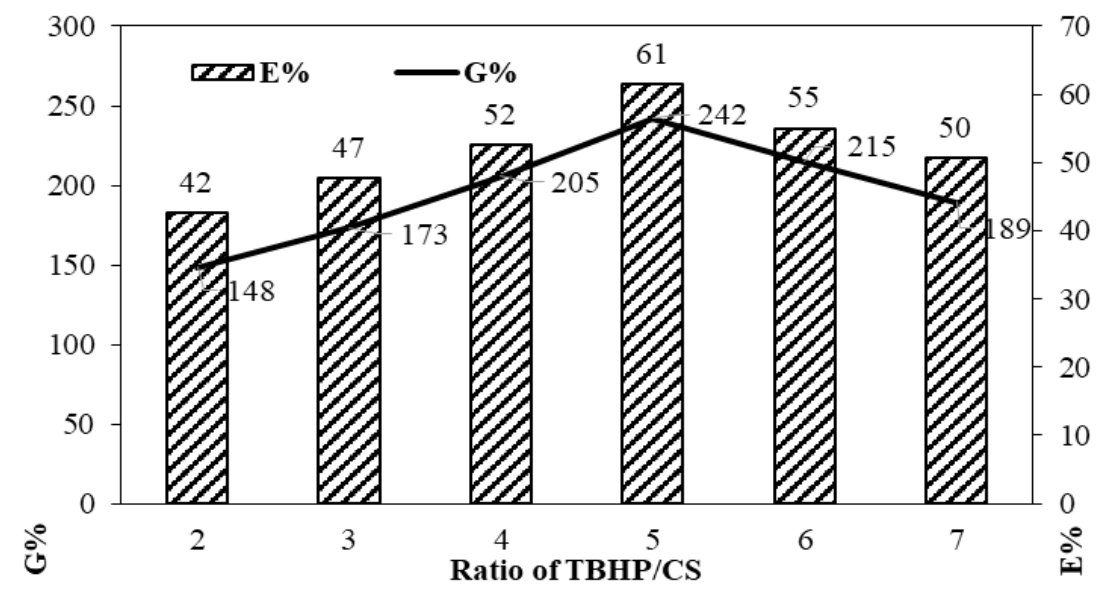

Fig. 3. Effect of TBHP content on $E \%$ and $G \%$ of $S_{0.75} X_{4} Y_{c}$ with $c=[2 ; 7]$.

Pablo Anbinder et al [2] used Potassium Persulfate (KPS) as an initiation. Their results showed the highest $\mathrm{G}=91.5 \%$, which is much lower than using TBHP in this paper $(242 \%)$. Besides, this research has the highest $\mathrm{E}=61 \%$ which is smaller than using KPS, reaching $91.5 \%$. It can be concluded that the action of TBHP is better than KPS for the copolymerization as well as homopolymerization.

\subsection{Assessment of the sample S0.75X4Y5 having the highest $G \%$ and $E \%$}

\subsubsection{FT-IR spectra}

As can be seen from the FT-IR spectra of CS, most of the presented peaks are related to carbohydrate structure. The broad and strong absorption peak at $3422 \mathrm{~cm}^{-1}(\mathrm{OH}$ and $\mathrm{NH}$ stretching), peak at $2960-2873 \mathrm{~cm}^{-1}(\mathrm{CH}$ stretching), $1637 \mathrm{~cm}^{-1}$ (NH bending) and the area around $1066-1164 \mathrm{~cm}^{-1}$ is common in spectra due to chitosan backbone.

Comparing the spectra of product $\mathrm{S}_{0.75} \mathrm{X}_{4} \mathrm{Y}_{5}$ before (b) and after Soxhlet (c), we find that the presence of a peak at $1735 \mathrm{~cm}^{-1}$ and $1164 \mathrm{~cm}^{-1}$, representing the $\mathrm{C}=\mathrm{O}$ stretch and $\mathrm{C}-\mathrm{O}-\mathrm{C}$ antisymmetric stretch of PBA. But the obvious difference between the copolymer and the mixture before Soxhlet is the fall of peak areas. It is interpreted that homopolymer PBA is removed. The comparison of CS (a) and copolymer CS-gPBA (c) indicates the disappearance of peak $1637 \mathrm{~cm}^{-1}$ corresponding to $\mathrm{N}-\mathrm{H}$ bending in primary amine. This asserts that PBA has been successfully grafted onto the CS molecules.

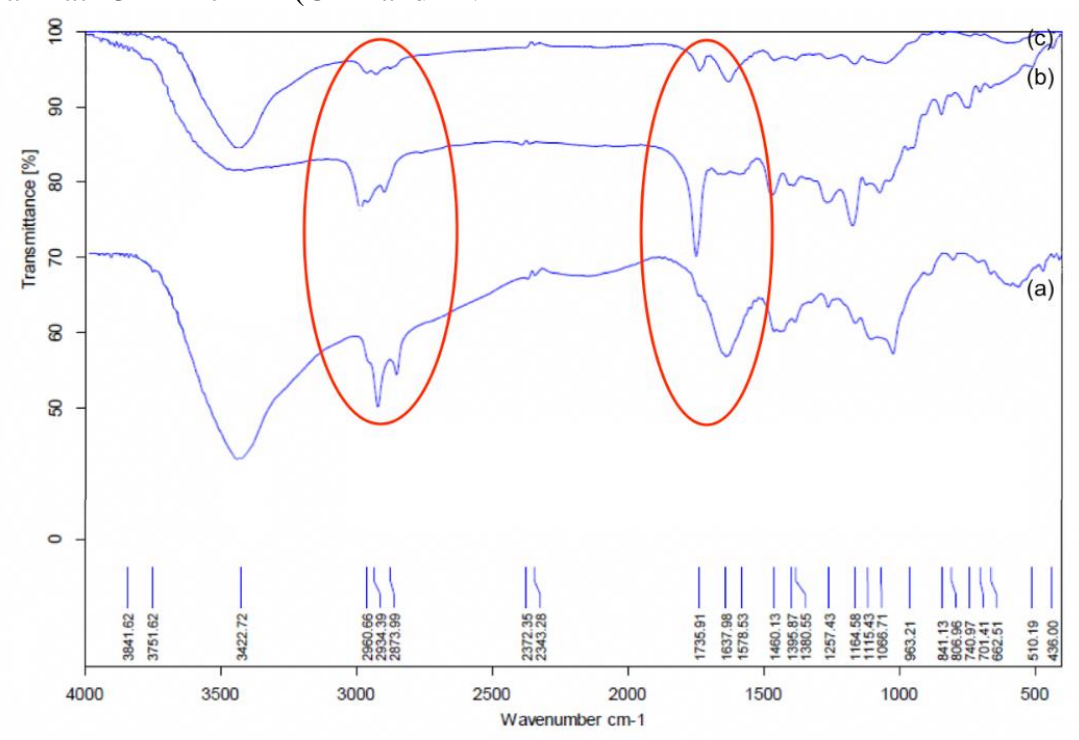

Fig. 4. IR spectra of chitosan (a), product $\mathrm{S}_{0.75} \mathrm{X}_{4} \mathrm{Y}_{5}$ before (b) and after Soxhlet (c). 


\subsubsection{Particle size and morphology}

The histogram particle size distribution of latex (Fig. 5) divides into two different areas: homopolymer area and copolymer area. As can be seen from the histogram, one peak is at about $0.1 \mu \mathrm{m}$ which is attributed to the copolymer and the other one belongs to homopolymer at approximately $100 \mu \mathrm{m}$.

Based on $\mathrm{G} \%$ and $\mathrm{E} \%$, it can be calculated that the weight ratio of copolymer/total weight of $\mathrm{S}_{0.75} \mathrm{X}_{4} \mathrm{Y}_{5}$ takes up about $70 \%$ and the weight ratio of homopolymer/total weight counts for $30 \%$ :

$$
\begin{aligned}
& \mathrm{E} \%=\frac{\mathrm{m}_{\text {Copolymer }}-\mathrm{m}_{\mathrm{CS}}}{\mathrm{m}_{\text {Copolymer }}+\mathrm{m}_{\text {Homopolymer }}-\mathrm{m}_{\mathrm{CS}}}=0.615 \\
& \mathrm{~m}_{\text {Copolymer }+ \text { Homopolymer }}=\frac{2.4215 \mathrm{~m}_{\mathrm{CS}}}{0.615}+\mathrm{m}_{\mathrm{CS}} \\
& \mathrm{G} \%=\frac{\mathrm{m}_{\text {Copolymer }}-\mathrm{m}_{\mathrm{CS}}}{\mathrm{m}_{\mathrm{CS}}}=2.4215 \\
& \mathrm{~m}_{\text {Copolymer }}=3.4215 \mathrm{~m}_{\mathrm{CS}}
\end{aligned}
$$

(3) \& (4) $=>\mathrm{m}_{\text {Copolymer }} / \mathrm{m}_{\text {Copolymer }+ \text { Homopolymer }} \approx 70 \%$.

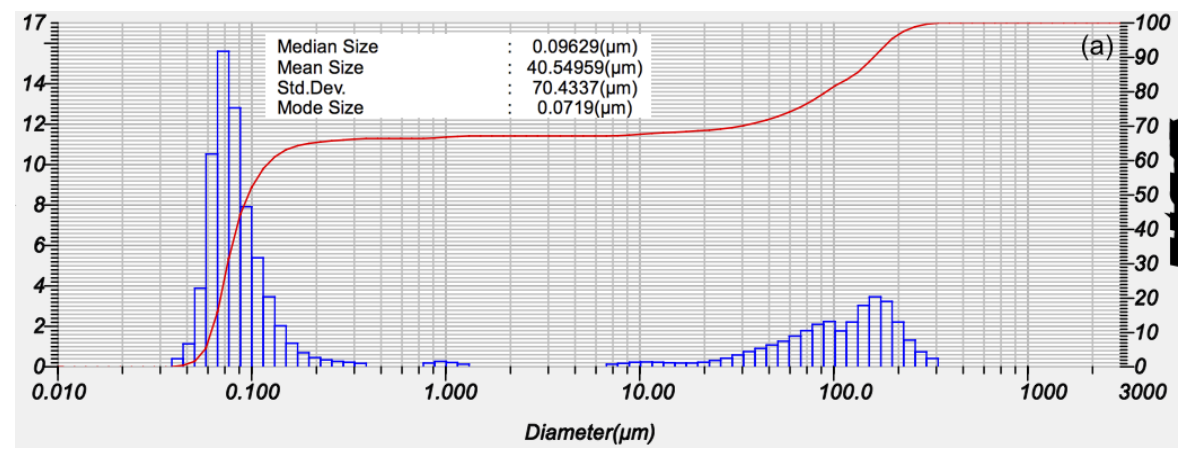

Fig. 5. Histogram particle size distribution of latex product $\mathrm{S}_{0.75} \mathrm{X}_{4} \mathrm{Y}_{5}$.

SEM micrographs of latex $\mathrm{S}_{0.75} \mathrm{X}_{4} \mathrm{Y}_{5}$ (Fig. 6) shows that the sphere shape of particles in latex product. The particle size is approximately under

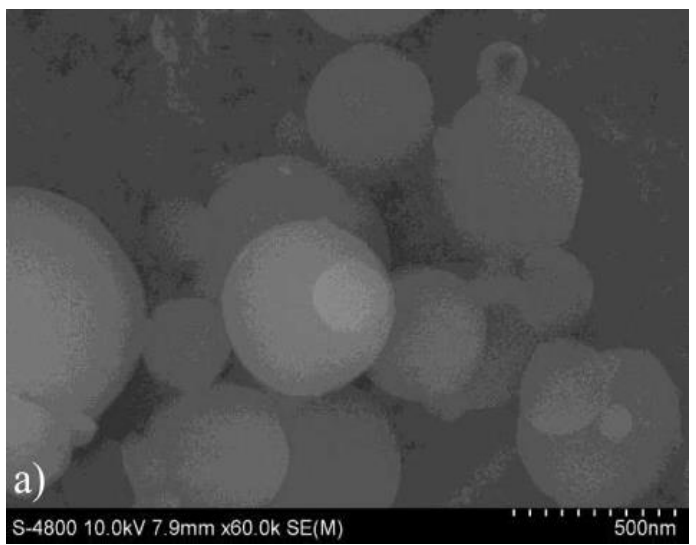

Fig. 6. SEM micrographs of latex $S_{0.75} X_{4} Y_{5}$ with magnification of: a) 60000 times and b) 5000 times.

\subsubsection{DSC thermal properties}

To analyze the difference between CS-g-PBA before and after Soxhlet, DSC curves are obtained (Fig. 7). It is well-known that glass transition temperature $\mathrm{T}_{\mathrm{g}}$ of $\mathrm{PBA}$ is $-54^{\circ} \mathrm{C}$ [9] and the curve (b) determines clearly $\mathrm{T}_{\mathrm{g}}$ of CS-g-PBA is $54.77^{\circ} \mathrm{C}$ when the mixture includes both homopolymer and copolymer. On the other hand, $\mathrm{T}_{\mathrm{g}}$ increases to $-20.27^{\circ} \mathrm{C}$ (curve a) that proves the absolute removal of homopolymer PBA and this
$0.5 \mu \mathrm{m}$ and relatively uniform that attributes to copolymer particles. These pictures coincide with histogram particle size distribution.

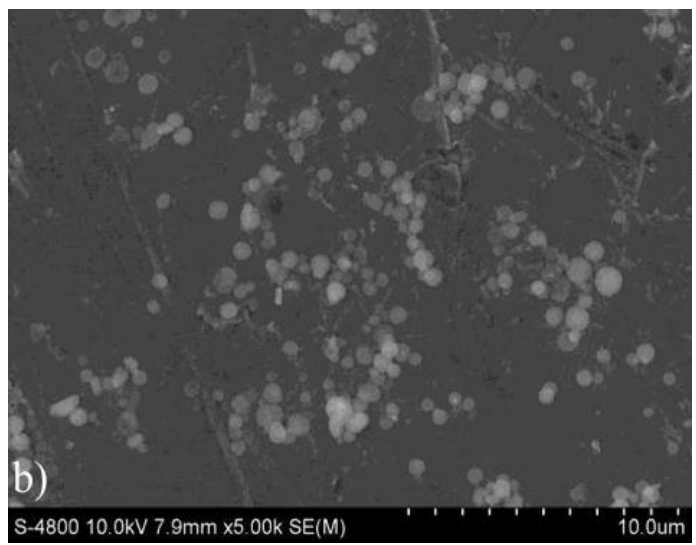

is $\mathrm{T}_{\mathrm{g}}$ of copolymer CS-g-PBA. There is a single endothermic peak at $153.36^{\circ} \mathrm{C}$ (before Soxhlet), which attributes to absorbed moisture and this peak goes up to $163.57^{\circ} \mathrm{C}$ with the extracted product. It is due to the interaction between copolymer CS-g-PBA and moisture after extraction is stronger than the mixture with the presence of homopolymer because copolymer is no longer shielded by homopolymer. This makes the temperature to remove moisture is higher than the mixture of two polymers. 


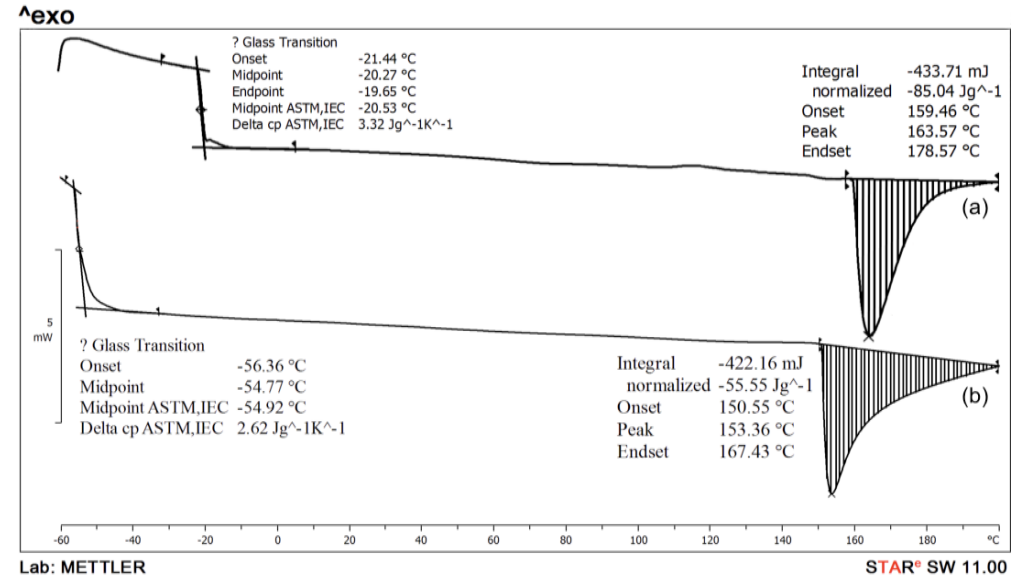

Fig. 7. DSC curves of CS-g-PBA: a) After Soxhlet and b) Before Soxhlet.

\subsection{Antibacterial activity}

Fig. 8 and Fig. 9 illustrate the antibacterial activities of original $C S\left(\mathrm{~S}_{1.5} \mathrm{X}_{0} \mathrm{Y}_{0}\right)$ and modified CS having altered concentrations. As can be seen evidently, all of the samples are against bacteria extremely well (100\% reduction). By this, I mean that the grafting copolymerization which has no impact on the antibacterial ability of CS can be used to broaden applications of CS.

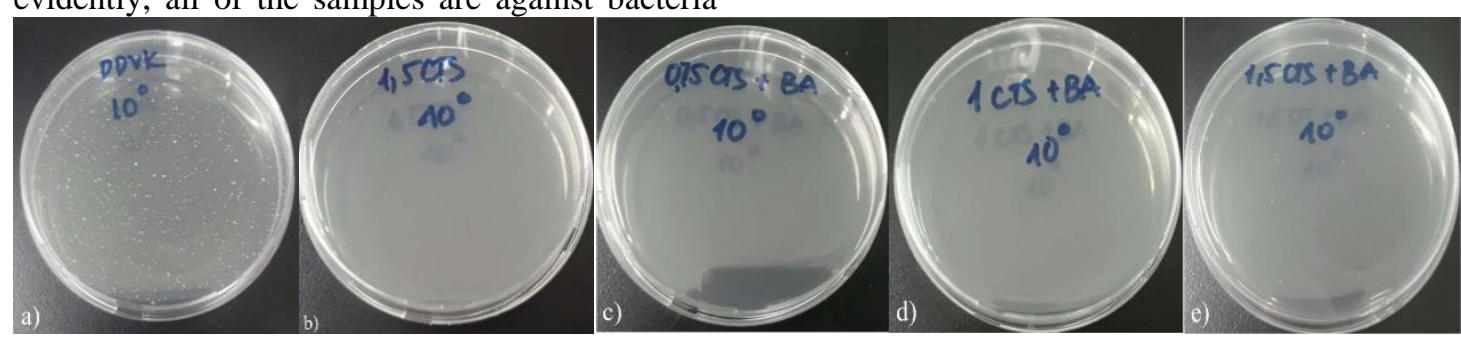

Fig. 8. Pictures of the petri dishes with:

a) Standard sample (bacterial suspension); b) $S_{1.5} X_{0} Y_{0}$; c) $S_{0.75} X_{4} Y_{5}$; d) $S_{1} X_{4} Y_{5}$; e) $S_{1.5} X_{4} Y_{5}$.

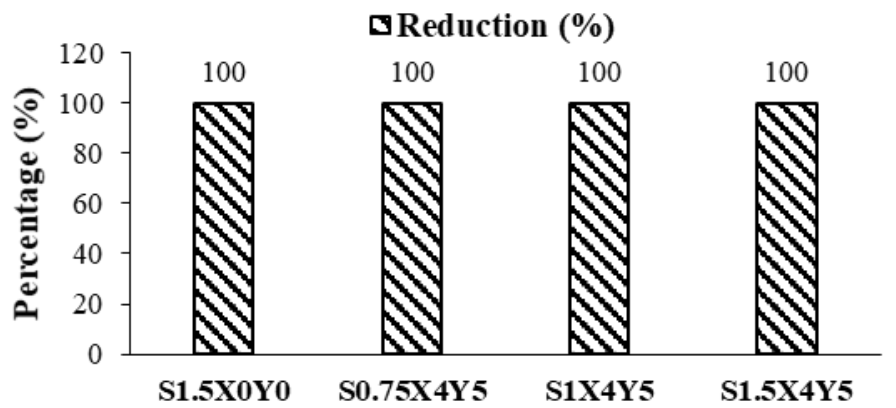

Fig. 9. Percent reduction for $S_{1.5} X_{0} Y_{0}, S_{0.75} X_{4} Y_{5}, S_{1} X_{4} Y_{5}, S_{1.5} X_{4} Y_{5}$ respectively.

\section{CONCLUSIONS}

In this article, CS-g-PBA copolymers were successfully synthesized by grafting BA onto the backbone of CS and this process was confirmed by IR spectroscopy analysis. From the results obtained, it can be concluded that:

- There is no influence on antibacterial activity caused by grafting copolymerization but CS has been improved some drawbacks involving higher flexibility (via declining $\mathrm{T}_{\mathrm{g}}$ ) and minimizing performance against water.

- CS concentration $0.75 \%$ in acetic acid is a better element to make it easier to create backbone macroradicals initiating the grafting copolymerization that rises $\mathrm{E} \%$ and $\mathrm{G} \%$.

- The high grafting efficiency percentage is obtained at $5 \mathrm{ml} / \mathrm{g}$ TBHP/CS. However, both of $\mathrm{G} \%$ and $\mathrm{E} \%$ decline shapely if the initiator is in excess. 


\section{REFERENCES}

[1]T. Provder, J. Baghdachi, "Core-Shell Particles Containing Poly(n-Butyl Acrylate) Cores and Chitosan Shells as a Novel Durable Antibacterial Finish", in Smart Coatings, 1st ed, USA: J. Am. Chem. Soc, 2007, pp. 15-26.

[2]P. Anbinder, C. Macchi, J. Amalvy, A. Somoza, "Chitosangraft-poly(n-Butyl Acrylate) copolymer: Synthesis and characterization of a natural/synthetic hybrid material", Carbohydra. Polym., vol. 145, pp. 86-94, Jul 2016, DOI: 10.1016/j.carbpol.2016.02.072.

[3]Q. Luo, H. Gao, L. Peng, G. Liu, Z. Zhang, "Synthesis of PEGylated chitosan copolymers as efficiently antimicrobial coatings for leather", J. Appl. Polym. Sci., vol. 133, no. 22, pp. 43465, Jan. 2016, DOI: 10.1002/APP.43465.

[4]M. Cabuk, Y. Alan, M. Yavuz, H. I. Unal, "Synthesis, characterization and antimicrobial activity of biodegradable conducting polypyrrole-graft-chitosan copolymer", Appl.Surf. Sci., vol. 318, pp. 168-175, Nov. 2014, DOI: $10.1016 /$ j.apsusc.2014.02.180.

[5]C. Radhakumary, P. D. Nair, S. Mathew and C. P. R. Nair, "Biopolymer Composite of Chitosan and Methyl Methacrylate for Medical Applications", Trends Biomater. Artif. Organs, vol. 18, no. 2, pp. 118-124, Jan. 2005.
[6]J. An, X. Yuan, Q. Luo, D. Wang, "Preparation of chitosangraft-(methyl methacrylate)/Ag nanocomposite with antimicrobial activity", Polym. Int., vol. 59, no. 1, pp. 6270, Jan. 2010, DOI: 10.1002/pi.2689.

[7]M.Chellapandian, M. R. V. Krishman, "Chitosan-poly (glycidyl methacrylate) copolymer for immobilization of urease", Process Biochem., vol. 33, no. 6, pp. 595-600, Aug. 1998, DOI: 10.1016/S0032-9592(98)80001-0.

[8]P. Li, J. Zhu, P. Sunintaboon, F. W. Harris, "New Route to Amphiphilic Core-Shell Polymer Nanospheres: Graft Copolymerization of Methyl Methacrylate from WaterSoluble Polymer Chains Containing Amino Groups", Langmuir, vol. 18, no. 22, pp. 8641-8646, Sep. 2002, DOI: $10.1021 / 1 \mathrm{a} 0261343$.

[9]W. Jakubowski, A. Juhari, A. Best, K. Koynov, T. Pakula, K. Matyjaszewski, "Comparison of thermomechanical properties of statistical: gradient and block copolymers of isobornyl acrylate and n-butyl acrylate with various acrylate homopolymers", Polym. J., vol. 49, no. 6, pp. 1567-1578, Mar. 2008, DOI: 10.1016/j.polymer.2008.01.047.

[10] C. N. Mai, "Synthesis of nanocomposite based on Chitosan-grafted-(n-butyl acrylate) and silver", B. Eng. Thesis, FMT, HCMUT, VNU-HCM, Viet Nam, 2018.

\title{
Biến tính chitosan với n-butyl acrylate - khả năng kháng khuẩn
}

\author{
La Thị Thái Hà*, Châu Ngọc Mai \\ Trường Đại học Bách Khoa, ĐHQG-HCM \\ *Tác giả liên hệ: cnmai.hcmut@gmail.com \\ Ngày nhận bản thảo: 01-4-2018; Ngày chấp nhận đăng: 19-9-2018; Ngày đăng: 31-12-2018
}

Tóm tắt-Polyme có nguồn gốc từ thiên nhiên như Chitosan (CS) là một trong những polymer tự nhiên dồi dào nhất trên thế giới có khả năng kháng khuẩn hiệu quả. Tuy nhiên, CS khá khó khăn trong việc đưa vào ứng dụng bởi vì những tính chất bất lợi của nó.

Trong bài báo này, CS được biến tính với n-butyl acrylate (BA) thông qua phản ứng đồng trùng hợp và sử dụng tert-butyl hydroperoxide (TBHP) làm chất khơi mào để thu được sản phẩm có nhiệt độ chuyển thuỷ tinh $\mathrm{T}_{\mathrm{g}}$ thấp hơn CS ban đầu và̀ mở rộng phạm vi ứng dụng nhưng vẫn giữ được khả năng kháng khuẩn tuyệt vời. Ảnh hưởng của các thông số đối với quá trình tổng hợp copolymer được nghiên cứu thông qua xác định phần trăm ghép (G\%) và hiệu quả ghép $(\mathrm{E} \%)$. Kết quả cho thấy $\mathrm{G} \%$ và $\mathrm{E} \%$ đạt giá trị cao nhất ở $242 \%$ và $61 \%$ với các điều kiện sau: $\mathrm{BA} / \mathrm{CS}=4 \mathrm{w} / \mathrm{w}, \mathrm{TBHP} / \mathrm{CS}=5 \mathrm{v} / \mathrm{w}$, $[\mathrm{TBHP}]=20 \mathrm{mM},[\mathrm{CS}]=\mathbf{0 , 7 5 \%} \mathrm{w} / \mathrm{v}$ trong dung dịch acetic acid $0,6 \%$ và phản ứng được thực hiện ở $\mathbf{9 0}^{\circ} \mathrm{C}$ trong 6 giờ.

Tù khoá - Kháng khuẩn, chitosan; ghép copolymer hoá; n-butyl acrylate; tert-butyl hydroperoxide. 